\title{
Scientifically substantiated directions of antileucosis provisions in modern animal husbandry
}

\author{
Bashchenko M., \\ academician NAAS, doctor of agricultural sciences \\ Mandygra M., \\ associate member NAAS, doctor of veterinary sciences \\ National Academy of Agrarian Sciences \\ Stegniy B., \\ academician NAAS, doctor of veterinary sciences \\ Gorbatenko S., Korneykov 0. \\ candidates of veterinary sciences \\ National Scientific Center "Institute of Experimental and Clinical Veterinary Medicine"
}

The purpose. Objective assessment of epizootic status of animal husbandry of Ukraine as to leucosis of cattle, determination of direction in irradiation of disease and provision of quality animal produce. Methods. Analysis of productivity of serological prophylactic medical examinations for leucosis of cattle of live farmings of various profiles which has been carried out in 2015 by the state laboratories of veterinary medicine and laboratory of study of leucosis of National centre of science «Institute of experimental and clinical veterinary medicine». Analysis of statistical paperwork. Results. It is fixed that owing to incoordination between diagnostic and inspection nets of veterinary medicine real epizootic state of animal husbandry of Ukraine for leucosis of cattle is distorted in the side of its artificial martempering. That results into unjustified understating of planned targets of diagnostic and prophylactic-and-improving provisions, and it complicates completion of irradiation of disease. Conclusions. Principal direction of provision of efficient anti-leucosis actions is the objective assessment of epizootic situation of branch at the level of live farmings of various classes and steady execution of veterinary legislation at implementation of the prophylacticand-improving program.

Key words: leucosis of cattle, anti-leucosis provisions, unsuccessful items, serological diagnostics.

The well-being of livestock industry for bovine leukosis is provided with strict implementation of legislated livestock serological examination's requirements and herd's rotation when elimination of the disease, depending on the level of its infection with leukosis virus. In some cases, when it comes to sporadic detection of animals infected with leukosis virus, treatment program's regulations require removal from herd and slaughter of compromised part of livestock. In other cases, when big number of livestock infected with leukosis virus is detected, the treatment program assigns short-term isolation of infected reproductive-aged-animals to prevent major economic losses [1, 2]. These measures are realized both for maintenance of productivity in treated livestock, and to get offspring from infected animals, which is used when rearing healthy heifers for gradual replacement of temporary hold livestock of cows infected with leukosis virus [3, 4]. In particular cases, when over $50 \%$ of livestock are infected with bovine leukosis virus, complete replacement with externally brought healthy animals is the only acceptable measure for herd's health. Namely this scheme of treatment measures against leukosis, which is given in instructions for realization of these measures [5], significantly improved epizootic situation for bovine leukosis in Ukrainian livestock farming in the previous 20 years. Experience in effective finishing of treatment measures against bovine leukosis using these schemes is given in literature by researchers, practical veterinary specialists and heads of livestock farms [6-9]. 
The aim is to evaluate epizootic status of Ukrainian livestock industry objectively, to determine disease's eradication approach, as well as to ensure optimal quality of animal production.

Materials and methods. The effectiveness of treatment measures against bovine leukosis in Ukrainian livestock industry for the past 20 years has been evaluated. The epizootic status of modern livestock industry for bovine leukosis has been analyzed in farms with different levels of submission. Own recent research results of epizootic and serological monitoring in livestock for bovine leukosis, as well as reports of state veterinary laboratories about epizootic status for bovine leukosis in Ukrainian livestock industry for 2015 have been used. To find out real epizootic status of Ukrainian livestock industry for bovine leukosis, informative capability of State Research Institute of Laboratory Diagnostics, Veterinary and Sanitary Expertise (SRILDVSE) and Ukrainian State Veterinary and Phytosanitary Service (USVPS) about above mentioned issue for the end of 2015 has been compared.

Results. In 1990s, bovine leukosis was the most widely spread infectious chronical disease in cattle in Ukraine: in 4469 collective livestock farms out of 11687 (by the end of 1997), various levels of animals infected with bovine leukosis virus were detected, and mostly, bigger numbers of animals were infected. At that time, serological method for early indication of animals infected with bovine leukosis virus had already been implemented in state region and district veterinary laboratories, therefore, treatment program against leukosis took on positive dynamics. The number of collective farms with bovine leukosis has been detected within 1997-2015 and in should be noted that it has been steadily decreasing each year (image).

When at the beginning of 1997 the number of farms with leukosis reached $4469(38,2 \%$ of total number of industrial and pedigree farms), it has decreased subsequently. Definitely, the number of industrial farms decreased each year as well. However, the ratio of farms with leukosis in relation to their total number constantly shows positive movements to the issue of epizootic wellness for bovine leukosis in Ukrainian livestock industry. When number of farms with this disease was minimized in recent years (2-6), statistical report of the Ukrainian State Veterinary and Phytosanitary Service for the end of 2015 demonstrates final completion of treatment program against leukosis; last outbreaks of the disease in Zhytomyr and Kharkiv regions were eradicated in the beginning of October, 2015.

The results of research conducted in the leukosis laboratory of National Scientific Center "Institute of Experimental and Clinical Veterinary Medicine", as well as analysis materials from Ukrainian state veterinary laboratories for serological examination for bovine leukosis suggest that in previously (1,5-2 years ago) treated regions animals which are positive on leukosis are occasionally detected. Such sporadic relapse cases recently occurred in farms in Kharkiv, Sumy, Zhytomyr, Poltava, Vinnytsia, Volyn and other regions. According to specialists, in most cases, it is connected with carelessness when conducting of final treatment measures against leukosis. Virus carriers after prolongation of incubation period in individual animals are meant. It should be noted that, according to literature [10], the incubation period as stage of the disease in individual animals may last for 250-500 days. In some cases, relapses were caused by bringing of animals infected with bovine leukosis to healthy herd, both imported and bought in the domestic market without proper epizootic analysis of purchased livestock. Long keeping of animals infected with bovine leukosis among household livestock plays an important role - disease's manifestation in healthy herds is provoked by direct and indirect contact of these animals with livestock from industrial farms. 


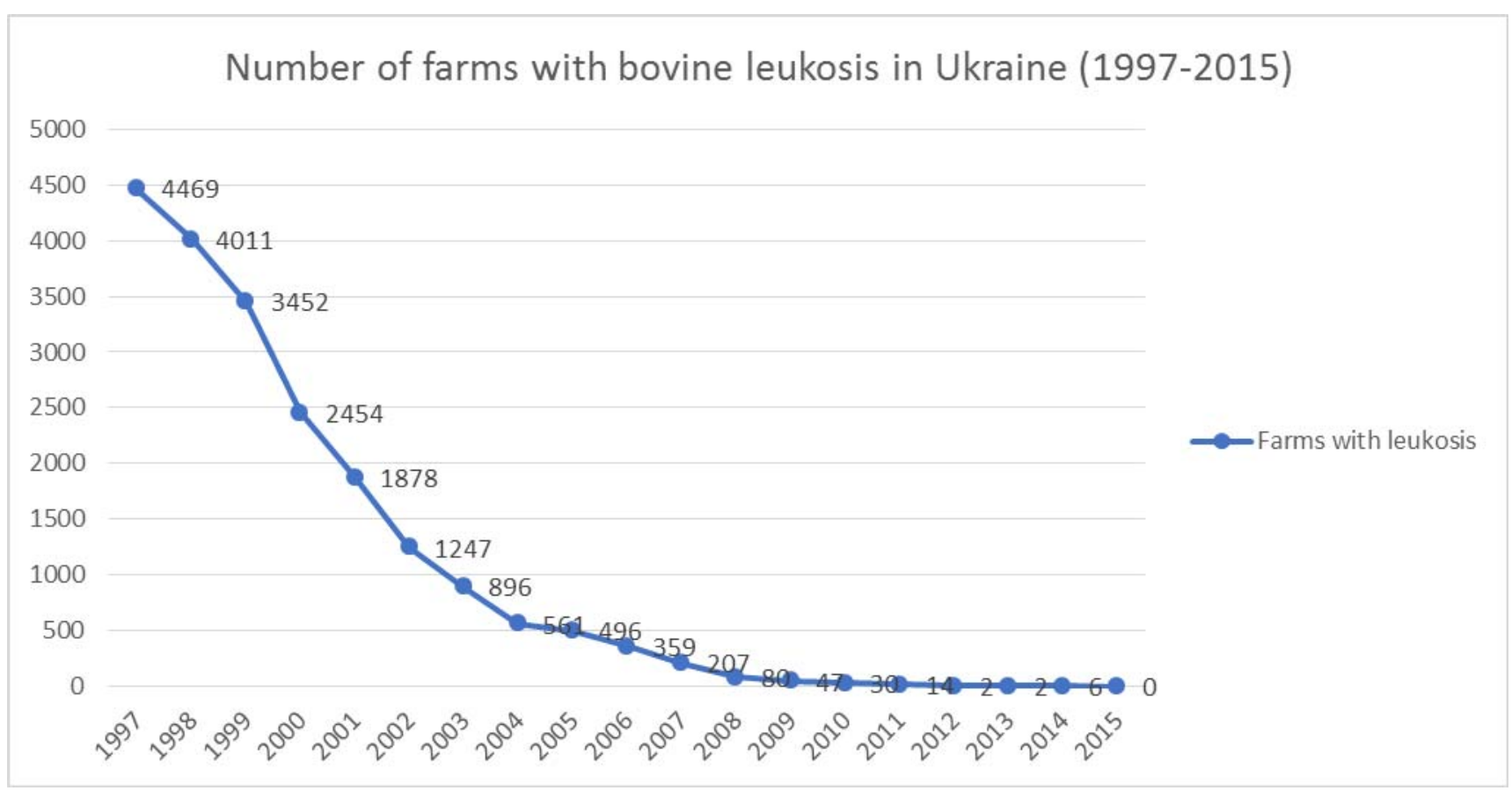

When talking about directions of measures against bovine leukosis in modern livestock farming, it is should be focused on the necessity of coordination between all branches which control epizootic situation and have an impact on processing, namely diagnostic and inspecting networks of veterinary surveillance, the last one is controlled by USVPS and its subsidiaries on regional and district levels. Our analysis of research results obtained throughout 9 months of 2015 reveals that this coordination is insufficient, and it has negative influence both on real evaluation of epizootic status for bovine leukosis in Ukrainian livestock farming, and on volumes of preventive measures, as well as their effectiveness (table).

When according to data of USVPS, 1314 infected with bovine leukosis animals were detected in Ukrainian livestock farming throughout above-mentioned period, the research results of state veterinary laboratories suggest about detection of 9388 positive animals. Moreover, statistical reports of USVPS show cases of bovine leukosis only in four regions (Vinnytsia, Zhytomyr, Poltava and Kharkiv). Serologic research results of Ukrainian state diagnostic units show that animal infected with bovine leukosis virus were registered throughout the whole this period in livestock farms of all regions un Ukraine, excepting Zakarpattia and Ivano-Frankivsk regions. Besides, it is concerned with mass serological positiveness in animals against leukosis antigen: hundreds - in Volyn, Dnipropetrovsk, Donetsk, Zaporizhia, Kirovograd, Odessa, Kherson, Cherkassy and Chernihiv; and over thousands of individuals infected with leukosis virus - in Vinnytsia, Rivne and Sumy regions. This raises a fair question - despite veterinary legislation, why the results of serological examination for bovine leukosis obtained by state veterinary laboratories are ignored and not recorded in official reports? As a result, measures which are necessary and provided by the current legislation, namely providing of restrictions and treatment measures, based on regular short-framed serological studies of nominally healthy herd with removing of infected animals for disruption of epizootic chain, are not implemented.

It should be noted that epizootic status of Ukrainian livestock industry for bovine leukosis, as well as the presence of infected areas, which are defined in USVPS statistical report, are used as the basis for planning of diagnostic tools' amount to supply state veterinary laboratories for control of livestock health during the next calendar year. Volumes of diagnostic studies for 2015 have been determined. Because of the lack of communication between diagnostic and inspecting branches, which also had occurred in previous years, only 3,505 out of 3,897 million serologic studies were 
planned $-89 \%$ of total livestock number. That is to say that it was planned to carry out single serological control only for $89 \%$ of total number of animals. And this plan was accepted, when positive for bovine leukosis animals were detected in farms almost in every region. Such circumstances require as least 8-9 million serologic studies throughout the year. Even these extremely depressed plans of diagnostic studies were only 66,7\% completed as of the beginning of October, 2015 (see the table).

\section{Epizootic status for bovine leukosis as of 01.10.2015 according to USVPS and SRILDVSE}

\begin{tabular}{|c|c|c|c|c|c|c|c|c|c|c|}
\hline \multirow[b]{2}{*}{ Region } & \multirow[b]{2}{*}{$\begin{array}{c}\text { Livestock } \\
\text { number, } \\
\text { thousand } \\
\text { s }\end{array}$} & \multirow[b]{2}{*}{$\begin{array}{c}\text { Studies } \\
\text { planned } \\
\text { for year, } \\
\text { thousand } \\
\text { s }\end{array}$} & \multirow[b]{2}{*}{$\begin{array}{l}\text { Studies } \\
\text { have been } \\
\text { conducted } \\
\text {, } \\
\text { thousands }\end{array}$} & & $\begin{array}{r}\text { logical stu } \\
\text { Number } \\
\text { animals }\end{array}$ & $\begin{array}{l}\text { es } \\
\text { infected } \\
\text { detected }\end{array}$ & \multicolumn{4}{|c|}{$\begin{array}{l}\text { Number of } \\
\text { infected farms }\end{array}$} \\
\hline & & & & $\begin{array}{c}\text { Plan's } \\
\text { completio } \\
\text { n rate, \% }\end{array}$ & $\begin{array}{l}\text { Accordin } \\
\text { g to } \\
\text { USVPS }\end{array}$ & $\begin{array}{c}\text { According } \\
\text { to } \\
\text { SRILDVS } \\
E\end{array}$ & 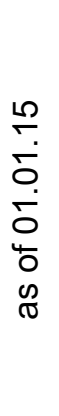 & 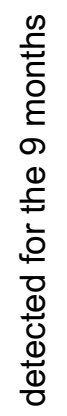 & 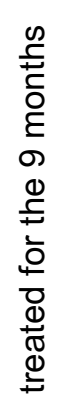 & 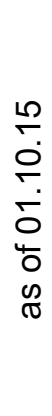 \\
\hline Vinnytsia & 301,6 & 270,0 & 202,6 & 75,02 & 16 & 1335 & 1 & - & 1 & - \\
\hline Volyn & 168,3 & 180,0 & 101,0 & 56,12 & - & 232 & - & - & - & - \\
\hline $\begin{array}{c}\text { Dnipropetrovs } \\
\mathrm{k}\end{array}$ & 133,6 & 135,0 & 97,1 & 71,90 & - & 339 & - & - & - & - \\
\hline Donetsk & 94,6 & 77,1 & 43,2 & 56,05 & - & 249 & - & - & - & - \\
\hline Zhytomyr & 183,8 & 158,1 & 102,1 & 64,58 & 291 & 672 & - & 1 & 1 & - \\
\hline Zakarpattia & 132,0 & 80,6 & 72,0 & 89,33 & - & - & - & - & - & - \\
\hline Zaporizhia & 105,6 & 90,7 & 67,2 & 74,18 & - & 309 & - & - & - & - \\
\hline $\begin{array}{c}\text { Ivano- } \\
\text { Frankivsk }\end{array}$ & 169,1 & 57,1 & 39,6 & 69,30 & - & - & - & - & - & - \\
\hline Kyiv & 135,8 & 145,6 & 99,8 & 68,58 & - & 598 & - & - & - & - \\
\hline Kirovograd & 108,3 & 83,3 & 66,7 & 80,13 & - & 151 & - & - & - & - \\
\hline Luhansk & 71,4 & 75,6 & 44,5 & 58,80 & - & 8 & - & - & - & - \\
\hline Lviv & 210,3 & 260,8 & 133,3 & 51,11 & - & 10 & - & - & - & - \\
\hline Mykolaiv & 132,4 & 111,9 & 81,5 & 72,82 & - & 47 & - & - & - & - \\
\hline Odessa & 191,7 & 213,4 & 123,2 & 57,75 & - & 254 & - & - & - & - \\
\hline Poltava & 256,7 & 208,6 & 116,1 & 55,66 & 11 & 214 & - & 1 & 1 & - \\
\hline Rivne & 154,2 & 122,6 & 80,8 & 65,87 & - & 1052 & - & - & - & - \\
\hline Sumy & 148,3 & 129,0 & 113,6 & 88,05 & - & 1205 & - & - & - & - \\
\hline Ternopil & 163,3 & 111,1 & 58,9 & 52,98 & - & 15 & - & - & - & - \\
\hline Kharkiv & 192,3 & 137,8 & 111,9 & 81,23 & 996 & 1694 & 5 & 5 & 10 & - \\
\hline Kherson & 114,2 & 128,9 & 75,9 & 58,89 & - & 151 & - & - & - & - \\
\hline Khmelnystkyi & 229.9 & 261,1 & 170,8 & 65,42 & - & 84 & - & - & - & - \\
\hline Cherkassy & 192,5 & 175,9 & 107,2 & 60,96 & - & 138 & - & - & - & - \\
\hline Chernivtsi & 98,2 & 94,7 & 65,2 & 68,81 & - & 6 & - & - & - & - \\
\hline Chernihiv & 208,9 & 196,0 & 164,0 & 83,68 & - & 625 & - & - & - & - \\
\hline Total & 3897,0 & 3504,9 & 2338,2 & 66,71 & 1314 & 9338 & 6 & 7 & 13 & - \\
\hline
\end{tabular}

By the beginning of October, plans of diagnostic studies for leukosis had been $51-52 \%$ completed in few regions (Lviv and Ternopil), 65-70\% (Rivne, Dnipropetrovsk and some other regions), and in limited cases $-80-85 \%$. State veterinary laboratories are supplied with test kits for identification of animals infected with leukosis virus, as required by planned tasks for serological diagnostics. Thereby, because of the incoordination between diagnostic and inspecting networks, there are no real planning of measures based on epizootic status for livestock treatment against leukosis, reliable control of postepizootic well-being of livestock farming after finishing of treatment measures, and, in its turn, secure control for preventing of disease's relapses in farms without leukosis. 


\section{Conclusions}

The main direction for implementation of effective measures against bovine leukosis is objective assessment of industry's epizootic situation in livestock farms, as well as strict applying of veterinary laws when realizing of preventive and treatment program. To prevent disease's relapses, the restrictions' removal for completion of treatment measures against leukosis, as well as terms of control surveillance in imported and domestically bought livestock must be aligned with disease's pathogenesis features and length of its incubation period.

\section{Bibliography}

1. Sovremennыe aspektы leykoza krupnoho rohatoho skota/B.T. Stehnyy, O.V. Shapovalova, S.K. Horbatenko, A.N. Korneykov//Vet. medytsyna mezhved. temat. nauch. sb. - Kh., 2013. - Vыр. 97. - S. $242-255$.

2. Suchasni pidkhody shchodo diahnostyky ta ozdorovlennya neblahopoluchnykh stosovno leykozu velykoyi rohatoyi khudoby hospodarstv/B.M. Yarchuk, R.V. Tyrsin, A.Y. Krayevs'kyy [ta in.]//Ahrarni visti. - 2001. - \# 4. - S. $11-15$.

3. Kurylo M. Shlyakhy ozdorovlennya velykoyi rohatoyi khudoby vid leykozu/M. Kurylo, S. Horbatenko/Neterynarna medytsyna Ukrayiny. — 2004. — \# 5. - S. 20.

4. Napryamky zapobihannya retsydyvu epizootiyi leykozu velykoyi rohatoyi khudoby/ S.K. Horbatenko, O.V. Shapovalova, O.M. Kornyeykov ta in.//Vet. medytsyna: mizhvid. temat. nauk. zb. - Kh., 2014. - Vyp. 98. - S. $84-87$.

5. Instruktsiya z profilaktyky ta ozdorovlennya velykoyi rohatoyi khudoby vid leykozu. - Zatv. nakazom Derzh. kom. vet. medytsyny Ukrayiny 21.12.2007, \# 21; zareyestr. v Min. yustytsiyi Ukrayiny 11.01.2008 r., \# 12/14703. - K., 2008. - 8 s.

6. Udyak V.M. Ozdorovlennya hospodarstva vid leykozu velykoyi rohatoyi khudoby/V. M. Udyak, M.S. Mandyhra, N. V. Lyubar//Nauk. visn. vet. medytsyny: zb. nauk. pr. — Bila Tserkva, 2012. - Vyp. 9 (92). - S. $110-113$.

7. Yarchuk B.M. Suchasni aspekty ozdorovlennya hospodarstv neblahopoluchnykh shchodo leykozu velykoyi rohatoyi khudoby/B.M. Yarchuk, R.V. Tyrsin, O.V. Dovhal'//Epizootolohiya i profilaktyka infektsiynykh khvorob VRKh: tezy dop. mizhnar. nauk.-prakt. konf. (14 - 17 bereznya 2006). - K., 2006. - S. $89-90$.

8. Mandyhra M.S. Istoriya ozdorovlennya hospodarstv ta indyvidual'noho sektoru Dubenshchyny vid leykozu velykoyi rohatoyi khudoby/M.S. Mandyhra, M.V. Romanyuk, Yu.M. Tomko//Zdorov"ya tvaryn i liky. - 2010. - \# 9. - S. 18 - 20.9. The recent prevalence of bovine leukemia virus (BLV) infection among Japanese cattle/K. Murakami [et al.]//Vet. Microbiol. - 2011. - V. 148, № 1. P. $84-88$.

10. Leykoz velykoyi rohatoyi khudoby: epizootolohichnyy monitorynh ta shlyakhy borot'by/ V. O. Busol [ta in.]. - Rivne: Dotsent, 2012. - $87 \mathrm{~s}$. 